\title{
VLOGA IN POMEN OSNOVNIH OSKRBNIH SREDIŠČ V SISTEMU POSELITVE SLOVENIJE*
}

\author{
Helena Šolar ${ }^{* *}$
}

\section{Izvleček}

Vloga in pomen osnovnih oskrbnih središč v sistemu poselitve sta opredeljena na podlagi analize veljavne resorne zakonodaje in normativov ter analize stanja $v$ prostoru na podlagi podatkov in terenskega dela. Z lokacijo dejavnosti in vzpodbud lahko država vpliva na razvoj osnovnih oskrbnih središč in njihovih zaledij. Na ta način usmerja razvoj celotnega sistema poselitve in različnih poselitvenih območij in zagotavlja skladnejši regionalni razvoj.

Ključne besede: Geografija naselij, centralna naselja, kvartarne dejavnosti, Slovenija

\section{THE ROLE AND IMPORTANCE OF BASIC SUPPLAY CENTERS IN THE SLOVENE SETTLEMENT SYSTEM}

\section{Abstract}

The role and the importance of the basic supply centres have been defined on the basis of competent legislation and standards analysis and on the basis of data analysis and the field work. The development of basic supply centres can be promoted by the state instruments. Such space development orientation can influence the development of the whole settlement system and contribute to balanced regional development.

Key words: Geography of settlements, central settlements, quartiary activities, Slovenia

\footnotetext{
* Prispevek je nastal na podlagi lastnega magistrskega dela z naslovom Vloga in pomen osnovnih oskrbnih središč $\mathrm{v}$ sistemu poselitve $\mathrm{z}$ vidika centralnih dejavnosti kvartarnega značaja. Detajlnejša razdelava obravnavene problematike je na vpogled v knjižnici Oddelka za geografijo Filozofske fakultete. Enako velja za vire in literaturo, ki so bili uporabljeni v magistrskem delu.

** Mag., Ministrstvo za okolje in prostor, Urad RS za prostorsko planiranje, Dunajska 47, SI 1000 Ljubljana
} 


\section{UVOD}

Sistem poselitve je eden od osnovnih elementov, ki oblikujejo pokrajino. Je primarni predmet prostorskega planiranja, saj se nanj navezuje vsa infrastruktura in je od njega odvisna razporeditev večine dejavnosti v odprti pokrajini.

Osnovna cilja, ki jima sledimo pri načrtovanju razvoja poselitve, sta zagotavljanje enakovrednih življenjskih pogojev in skladnega regionalnega razvoja za vse prebivalce in vsa območja $\mathrm{v}$ Sloveniji. Vprašanje usmerjanja razvoja območij praznjenja, na katera sem se osredotočila $\mathrm{v}$ okviru svojega prispevka, je med ključnimi vprašanji nadaljnjega razvoja poselitve v Sloveniji. Predmet preučevanja so bila osnovna oskrbna središča in njihova vloga pri ohranjanju vitalne poseljenosti cele Slovenije Dileme nadaljnjega razvoja poselitve, ki jih obravnava prispevek, zadevajo razvoj demografsko ogroženih in strukturno šibkih območij, vlogo osnovnih oskrbnih središč $\mathrm{v}$ ohranjanju vitalne poseljenosti in vlogo države $\mathrm{v}$ zagotavljanju omrežij osnovnih centralnih dejavnosti kvartarnega značaja na območju cele Slovenije.

Rešitve na predstavljena vprašanja in dileme sem iskala $\mathrm{v}$ okviru razmeščanja dejavnosti vzgoje, izobraževanja, zdravstvenega varstva, zdravstva in kulture v osnovnih oskrbnih središčih. Prispevek obravnava rezultate analize vloge in pomena osnovnih oskrbnih središč $\mathrm{v}$ Sloveniji $\mathrm{z}$ vidika centralnih dejavnosti kvartarnega značaja.

\section{TEZA}

Demografsko ogrožena in območja $\mathrm{z}$ razvojnimi problemi bodo za razvojne vzpodbude vedno manj zanimiva, ker se bo tudi na področju kvartarnih dejavnosti ponudba vedno bolj oblikovala na podlagi tržnih načel in bo prišlo do koncentracije obsega in kakovosti storitev v območjih z večjo kupno močjo prebivalstva.

Če želimo ohraniti poseljenost celotnega slovenskega ozemlja in razpršeno poselitev kot izraz kvalitete in ne degradacije prostora, je pomembno, da ohranimo obstoječo mrežo kvartarnih centralnih dejavnosti $\mathrm{v}$ redko poseljenih in slabo dostopnih območjih. Država in lokalne skupnosti jo lahko ohranijo ali zagotovijo tudi na območjih, kjer to ni ekonomsko upravičeno, je pa potrebno zaradi zagotavljanja enakovrednih pogojev bivanja. Usmerjanje razvoja teh območij posredno pomeni usmerjanje razvoja celotnega sistema poselitve. Pomeni večjo kvaliteto bivanja in skladnejši regionalni razvoj.

Cilji, ki sem jih v analizi zasledovala, so bili spoznati pomen izbranih dejavnosti in ugotoviti odstopanja od meril za njihovo razmestitev, oceniti organizacijo in delovanje izbranih dejavnosti glede na dostopnost prebivalstva do dejavnosti in predlagati okvir za zasnovo razvoja lokalnih oskrbnih središč. 
Osrednji del prispevka zadeva analizo vzorca poselitve in analizo opremljenosti osnovnih oskrbnih središč, ki je sestavljena iz treh delov. Prvi del je analiza stanja v prostoru, drugi analiza veljavnih prostorskih dokumentov in področne zakonodaje, tretji del pa analiza rezultatov mnenjske ankete in javnomnenjskih raziskav.

Raziskovalno delo je temeljilo na izbranem sistemu središč in centralnih dejavnosti. Odločila sem se za sistem središč najnižje stopnje oskrbe in najosnovnejšo kvartarno oskrbo prebivalstva, ki obsega dejavnosti predšolske vzgoje in osnovnošolskega izobraževanja, dejavnost zdravstvenih ambulant in lekarn in dejavnost splošno izobraževalnih knjižnic.

\section{ANALIZA}

Razporeditev prebivalcev in naselij $\mathrm{v}$ Sloveniji je posledica naravno-geografskih razmer, zgodovinskega razvoja in politike skladnega regionalnega razvoja $\mathrm{s}$ policentričnim konceptom urbanizacije, ki je bil postavljen v začetku 70. let. Kot obvezno izhodišče je bil, $\mathrm{v}$ republiškem prostorskem planu, opredeljen z omrežjem regionalnih središč.

Omrežje urbanih središč je premalo učinkovito zaradi premajhne notranje funkcionalne in regionalne povezanosti. Ne zagotavlja namreč optimalnih gravitacijskih območij razvojnih središč v smislu zaposlovanja, oskrbe in storitev na celotnem območju Slovenije.

Slika 1: Zasnova urbanega omrežja (1986)

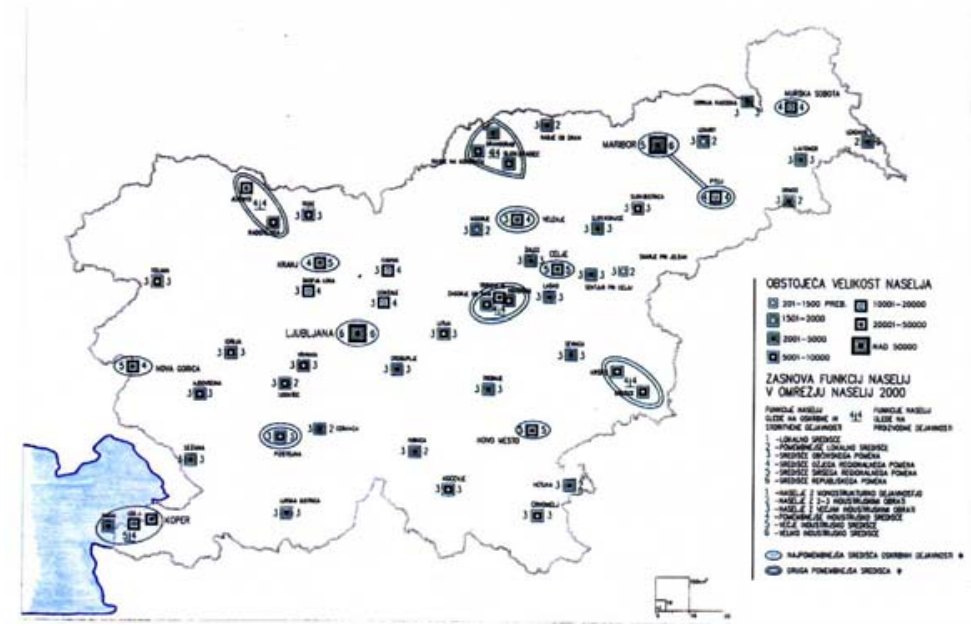

Prva pomembna značilnost slovenske poselitve je velika razpršenost, saj manj kot 2 milijona ljudi prebiva v nekaj manj kot 6 tisoč naseljih. 


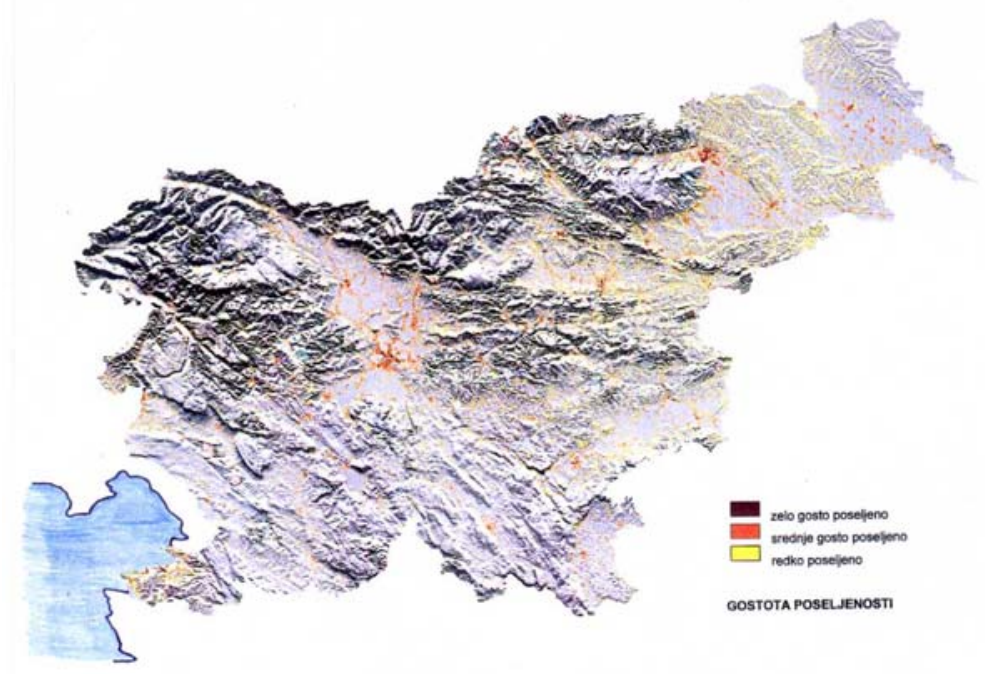

Obsežni procesi in območja demografskega praznjenja so druga pomembna značilnost poselitve v Sloveniji. V zadnjih desetletjih se namreč v dveh tretjinah vseh naselij število prebivalcev zmanjšuje. Glede na demografske značilnosti posameznih poselitvenih območij, je Slovenija razdeljena na območja koncentrirane urbanizacije, urbanizirano podeželje in pretežno ruralni prostor brez pomembnejših središč in populacijskega potenciala. Večina naselij, v katerih se število prebivalcev zmanjšuje, je v tradicionalnih ruralnih območjih, pretežno v goratem in obmejnem območju Slovenije. Na drugi strani so območja zgostitev prebivalcev in dejavnosti, po večini v večjih urbanih središčih in vzdolž glavnih infrastrukturnih povezav. V zadnjih desetletjih so v pokrajini prisotni tudi intenzivni procesi suburbanizacije.

Drugi del analize sem osredotočila na veljavno zakonodajo in normative. Za vsako posamezno dejavnost sem analizirala zakonski okvir in resorne normative za določitev lokacij, gravitacijskih območij in omrežja posamezne dejavnosti. Stanje sem osvetlila tudi $\mathrm{z}$ vidika minimalnih kriterijev Zakona o lokalni samoupravi za vzpostavitev občinskih središč.

\section{Vzgoja in izobraževanje}

Ustanoviteljice osnovnih šol in odgovorne za področje osnovnega izobraževanja so občine. K sredstvom posameznih, finančno manj sposobnih občin, se lahko dodajo državna sredstva iz proračuna.

V Sloveniji je bilo leta 1997431 samostojnih in 385 podružničnih šol. Veljavni normativi predvidevajo ustanovitev osnovnih šol za 400 - 600 šoloobveznih otrok ali 
3.500 - 5.000 prebivalcev. Na območjih, kjer ni zagotovljene polurne dostopnosti do osnovne šole in vrtca, je gravitacijsko območje lahko tudi manjše.

Slika 3: Osnovne šole in vrtci po občinah v Sloveniji (1997)

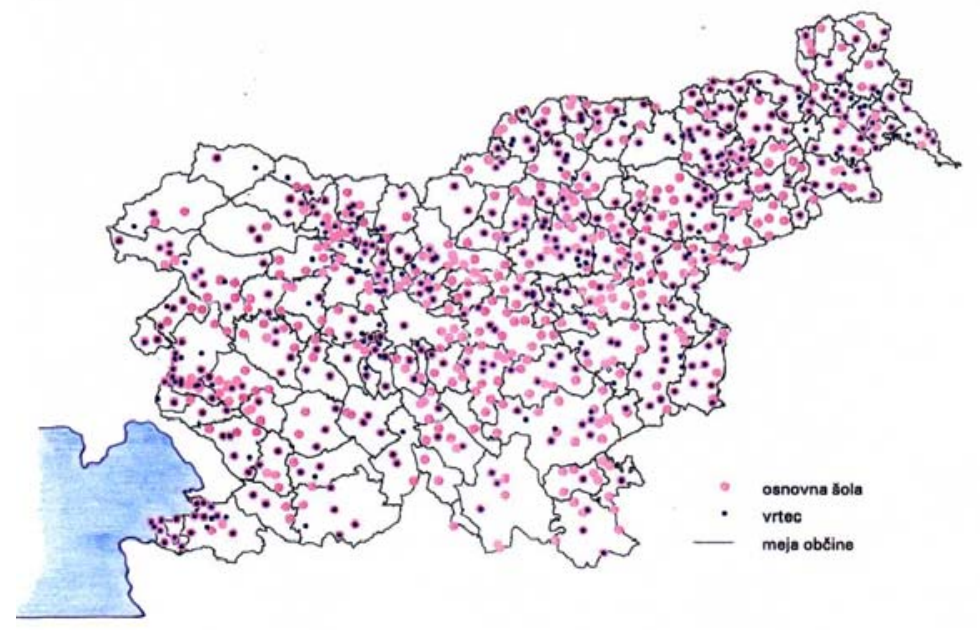

\section{Zdravstvo in zdravstveno varstvo}

Mrežo javne zdravstvene službe na primarni ravni, ki obsega zdravstveno in lekarniško dejavnost, oblikuje in uresničuje občina, s katero na demografsko ogroženih območjih sodeluje država. Zdravstveni dom je organiziran za eno ali več občin, odvisno od velikosti in števila prebivalcev. V Sloveniji je bilo leta 1997595 zdravstvenih domov ali ambulant. Lokacija tako zdravstvenega doma, kot tudi lekarne, naj bi zadovoljevala gravitacijsko območje 8.000 - 10.000 prebivalcev. Pomanjkljiva oskrba $z$ dejavnostjo osnovnega zdravstva in zdravstvenega varstva je prisotna v nekaterih občinah ob južni slovenski meji s Hrvatsko in v severovzhodni Sloveniji.

\section{Knjižničarska dejavnost}

Splošno izobraževalna knjižnica naj po normativih oskrbuje gravitacijsko območje 5.000 - 10.000 prebivalcev. Leta 1997 je bilo v Sloveniji 60 splošno izobraževalnih knjižnic. Naselja z manj kot 1500 prebivalci, ki so brez stalnega knjižničnega izposojevališča, oskrbujejo splošno izobraževalne knjižnice s potujočo knjižnico. 


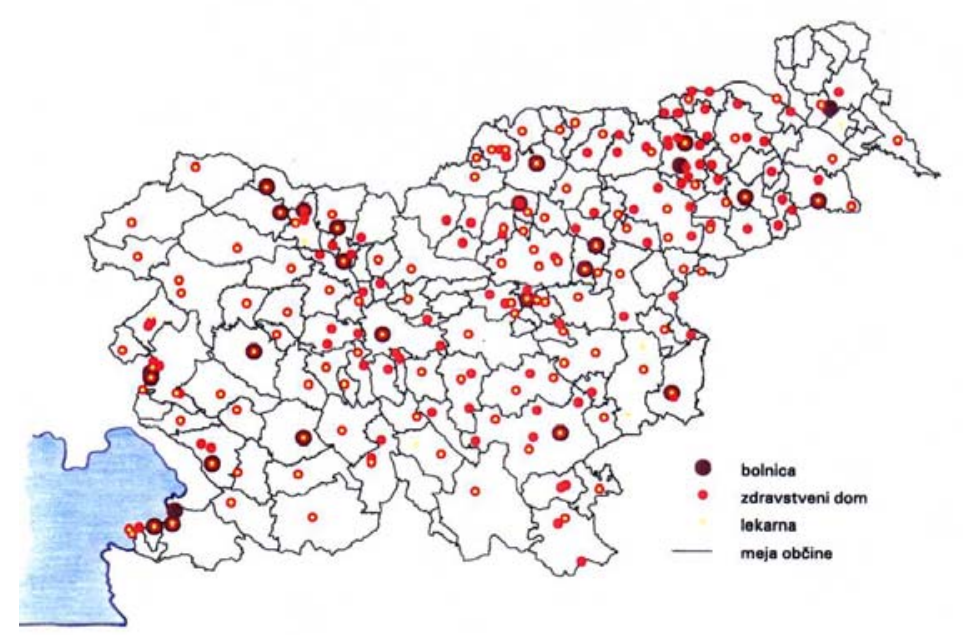

Slika 5: Splošno izobraževalne knjižnice po občinah v Sloveniji (1997)

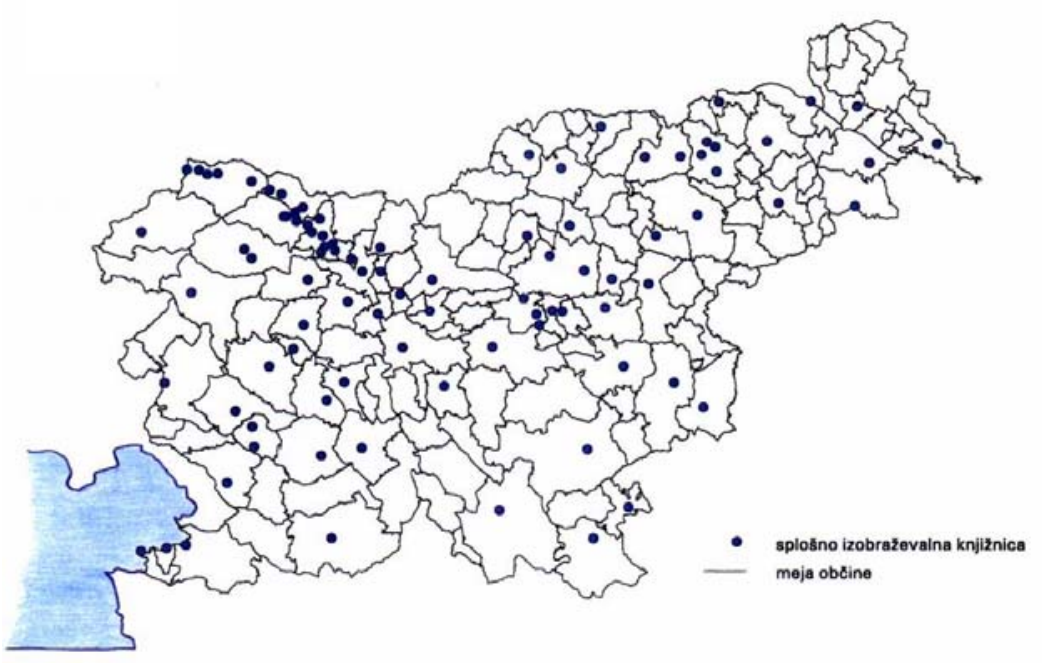

Rezultati analize kažejo, da je, glede na normativne kriterije, razporeditev dejavnosti $\mathrm{v}$ glavnem zadovoljiva, glede na enakomerno dostopnost do dejavnosti in enakovredne pogoje bivanja pa ne, predvsem na območjih, ki so demografsko ogrožena ali strukturno šibka. 
Tretji del analize so Anketa o ustreznosti razporeditve izbranih dejavnosti in javnomnenjske raziskave. Namen ankete, je bilo temeljitejše seznanjanje $\mathrm{z}$ objektivnimi razmerami na terenu in pridobivanje podatkov, ki jih uradna statistika ne spremlja.

Anketo po krajevnih skupnostih sem izvedla poleti 1997. Vprašalnik sem poslala 1245 krajevnim skupnostim. Vrnjenih sem dobila sem 756 ali $60 \%$ izpolnjenih vprašalnikov. Podatki, pridobljeni $\mathrm{z}$ anketo, so ovrednoteni kot kvalitativna ocena organizacije in delovanja osnovnih kvartarnih dejavnosti v prostoru. So subjektivna ocena kakovosti in dostopnosti do dejavnosti in dopolnilo bolj objektivnih podatkov, pridobljenih z analizo poselitvenega vzorca Slovenije in analizo veljavnih prostorskih dokumentov in področne zakonodaje.

Krajevne skupnosti, ki so odgovorile na anketni vprašalnik, sem za potrebe analize razdelila na tri tipe glede na njihovo lego v odnosu do občinskega središča (krajevne skupnosti na območjih mestnih občin, krajevne skupnosti na območjih središč nemestnih občin in krajevne skupnosti izven območij središč nemestnih občin). Odločitev se je izkazala za pravilno, ker analiza odgovorov kaže na različno aktualnost problematike $\mathrm{v}$ različnih tipih krajevnih skupnosti.

$\mathrm{Na}$ podlagi rezultatov ankete je bila oblikovana ocena ustreznosti prostorske razporeditve in kvalitete dejavnosti vzgoje in izobraževanja, zdravstva in zdravstvenega varstva in knjižničarske dejavnosti. Rezultati so predstavljeni na grafikonih v nadaljevanju.

Zaradi primerljivosti rezultatov med različnimi tipi krajevnih skupnosti, so na istem grafikonu prikazani podatki za vse tri tipe krajevnih skupnosti.

- KS v MO pomeni krajevne skupnosti na območjih mestnih občin,

- KS v SNO pomeni krajevne skupnosti na območjih središč nemestnih občin,

- KS izven SNO pa krajevne skupnosti izven območij središč nemestnih občin.

Glede na rezultate ankete so osnovne šole so najustrezneje locirane v krajevnih skupnostih $v$ središčih novih občin. S črno barvo je označeno obiskovanje osnovne šole, oziroma zdravstvenega doma $\mathrm{v}$ istem kraju, $\mathrm{z}$ belo barvo $\mathrm{v}$ drugem kraju iste občine, s sivo pa obiskovanje osnovne šole, oziroma zdravstvenega doma $\mathrm{v}$ drugi občini. 
Diagram 1 : Lokacija osnovne šole za večino otrok v krajevni skupnosti (1997)

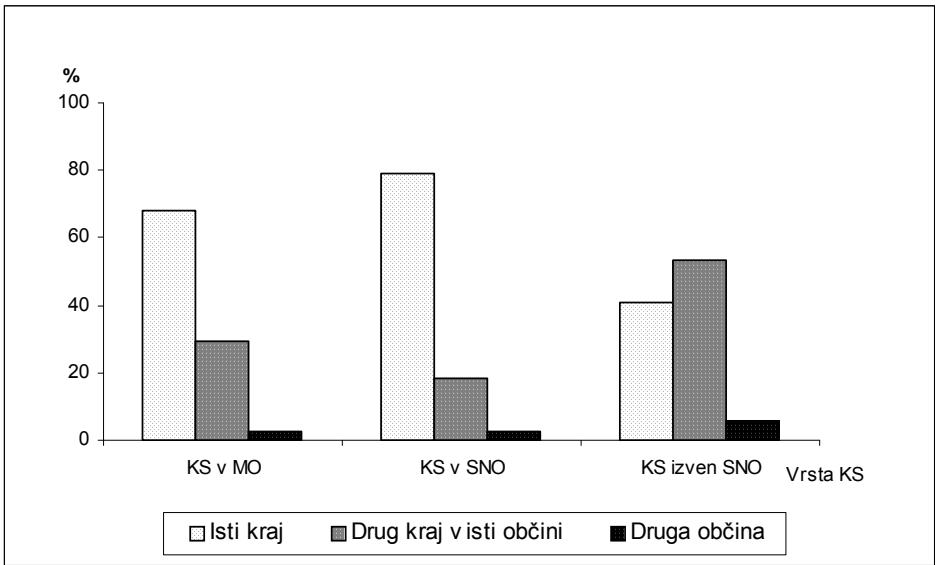

Diagram 2: Lokacija zdravstvenega doma za večino prebivalcev v krajevni skupnosti (1997)

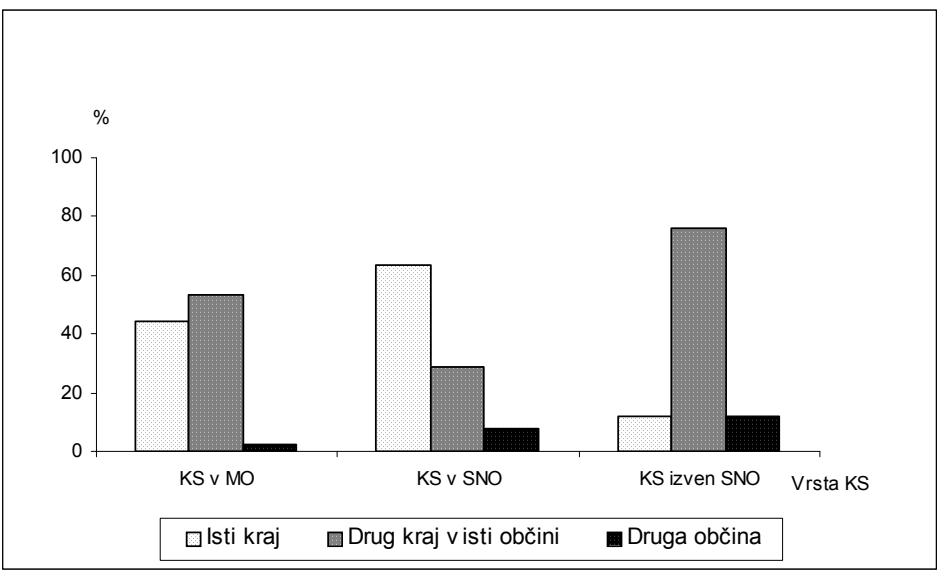

Tudi ustreznost lokacije zdravstvenih domov je najugodnejša v krajevnih skupnostih na območjih občinskih središč nemestnih občin. Približno polovica prebivalcev krajevnih skupnosti na območjih mestnih občin mora do zdravstvenega doma $\mathrm{v}$ sosednji kraj iste občine, na območjih izven središč nemestnih občin pa je ta delež skoraj $80 \%$.

V anketi sem postavila tudi vprašanje o kvalitativni ustreznosti lokacije osnovnih šol, vrtcev, zdravstvenih domov, lekarn in knjižnic. Kot je razvidno iz grafikonov, so pri vseh dejavnostih s kvalitativno ustreznostjo lokacije najbolj zadovoljni prebivalci krajevnih skupnosti na območju središč nemestnih občin, najmanj pa v krajevnih 
skupnostih izven njih. Črna barva predstavlja odgovor dobro, bela zadovoljivo, siva pa slabo.

Diagram 3: Kvalitativna ustreznost lokacije zdravstvenega doma za večino prebivalcev v KS (1997)

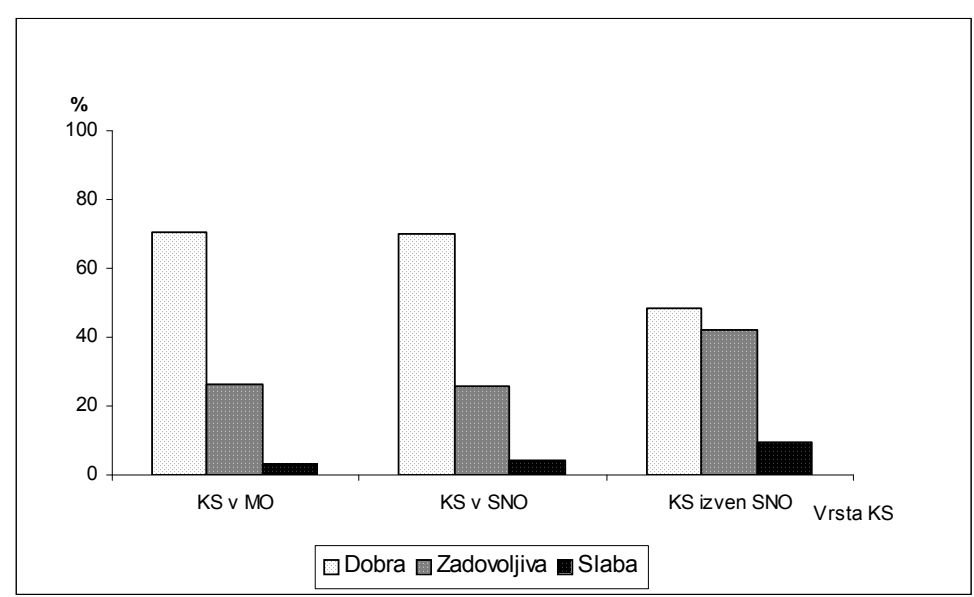

Diagram 4: Kvalitativna ustreznost lokacije osnovne šole za večino otrok v KS (1997)

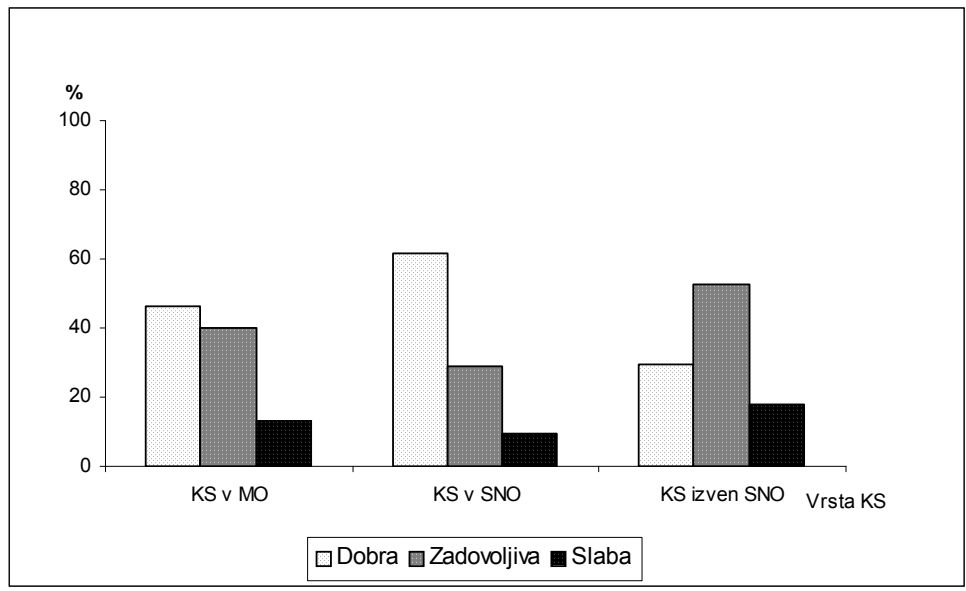

Glede na normativne kriterije in zakonsko določene pogoje minimalne oskrbe $\mathrm{z}$ dejavnostmi, lahko zaključim, da je oskrba z najosnovnejšimi centralnimi dejavnostmi 
kvartarnega značaja ustrezna. Glede na rezultate mnenjskega dela raziskave sta organizacija in delovanje osnovnih centralnih dejavnosti manj ustrezna, kar velja predvsem za območja demografske ogroženosti in tradicionalno slabše dostopnosti. Tako kvantitativna, kot tudi kvalitativna ustreznosti lokacije posamezne centralne dejavnosti z odmikom od razvojnih središč pada.

Država in lokalne skupnosti lahko poskrbijo za slabše opremljena območja z lokacijo dejavnosti osnovnega kvartarnega značaja $\mathrm{V}$ lokalna oskrbna središča in $\mathrm{Z}$ zagotavljanjem ugodnih lokacijskih in gospodarskih pogojev za delovanje služb in posameznikov $\mathrm{v}$ teh središčih. Spodbujanje razvoja je smiselno tam, kjer so za to naravni in lokalni razvojni potenciali in lokalna razvojna iniciativa. $\mathrm{Na}$ ta način bodo območja, ki jih je zajel proces praznjenja, postala spet privlačna za poselitev.

\section{ZAKLJUČEK}

Sklepni del prispevka obsega predlog strategije usmerjanja razvoja osnovnih oskrbnih središč in njihovih zaledij v Sloveniji.

Strategija razvoja poselitve bo temeljila na uveljavljenih načelih skladnega regionalnega in trajno uravnoteženega razvoja. $\mathrm{V}$ območjih zgostitve prebivalcev in dejavnosti, velja poudarek nameniti izboljševanju kvalitete bivanjskega standarda ob sanaciji in ohranjanju zdravega življenjskega okolja, na podeželju ohranjanju tipične arhitekture in oblikovne podobe naselij, predvsem $\mathrm{z}$ vidika povečevanja privlačnosti podeželja za bivanje, v območjih s specifičnimi razvojnimi neskladji pa obnavljanju in ohranjanju razvojnih potencialov teh območij, ki zagotavljajo nadaljevanje poseljenosti in ekonomske uspešnosti teh območij.

Nadaljnji razvoj poselitve $\mathrm{V}$ Sloveniji je potrebno načrtovati $\mathrm{V}$ skladu $\mathrm{z}$ naravnogeografskimi in socialno-ekonomskimi potenciali posameznih območij. Nadaljnji razvoj demografsko ogroženih območij smiselno vzpodbujati tam, kjer imajo naravne ali ustvarjene pogoje za nadaljnji razvoj. Ključnega pomena je lokalna razvojna iniciativa, brez katere še tako ugodni pogoji ostanejo nepomembni in neizkoriščeni.

Lokalna središča $\mathrm{v}$ sistemu poselitve so osnovni nosilci razvoja in ohranjanja poseljenosti in ekonomske uspešnosti podeželskih in strukturno šibkejših območij. Podobno kot razvoj območij, naj tudi razvoj lokalnih središč temelji na njihovih naravnogeografskih in socialno-ekonomskih potencialih in na podlagi lokalne razvojne iniciative. Le tako bo namreč lahko učinkovit in bodo lokalna središča $\mathrm{z}$ osnovno prometno in družbeno infrastrukturo, kot tudi $z$ ostalimi dejavnostmi in delovnimi mesti, pripomogla tudi k razvoju in revitalizaciji njihovih zaledij. 


\title{
THE ROLE AND IMPORTANCE OF BASIC SUPPLAY CENTERS IN THE SLOVENE SETTLEMENT SYSTEM
}

\begin{abstract}
Summary
The article deals with the results of the research on the role and the importance of the basic supply centers from the point of view of the quartiary central activities. The theme is of crucial importance for the future settlement development in Slovenia, especially in the demographically endangered and structurally weak areas.

The present settlement pattern in Slovenia is declared a quality and a comparative advantage. Such space development orientation can, by state instruments, promote the development of basic supply centers also where the criteria of economic effectiveness are subordinated to those of equal living conditions and balanced regional development. The promotion of basic supply centers and their hinterlands influences the development of the whole settlement system, creates higher living quality for all the inhabitants and contributes to balanced regional development.
\end{abstract}

The most important dilemmas in settlement development, dealt with in the article, are the development of depopulation and structurally weak areas, the role of the basic supply centers in preserving of the vital settlement of the whole Slovene national territory and the role of the state in creating of the basic quartiary activities' networks.

The aims of the research were to analyze the role of selected quartiary activities, to evaluate the organization of quartiary activities according to normative criterion, to evaluate the organization of quartiary activities according to settlement dispersion and equal accessibility for everyone and to propose a framework for the spatial organization of basic supply centers and basic quartiary activities networks. These aims were approached through the settlement pattern analysis, based on the settlement pattern data analysis, on the analysis of spatial and sector legislation dealing with the basic quartiary activities and on the analysis of data, collected by a field research carried out in the local communities.

Basic supply centers are bearers of development economic effectiveness in the demographically endangered and structurally weak areas. The state and the local authorities can promote the development of these areas by providing the needed (social) infrastructure in the areas where the criteria of economic justification is not meet. The settlement development is to be stimulated in the areas where natural and built development potentials as well as local development initiative are present.

The settlement development strategy must ground on the principle of sustainable and balanced regional development. The stress should be given to improvement of living 
standard (sanitation of degraded areas) in the congestion areas, to preservation of regional identity and to increased attraction for settlement in the demographically endangered areas and to renewal of development potentials in the structurally weak areas. The strategy described will contribute to settlement continuity and economic efficiency of the whole Slovene national territory. 